\title{
The user interface design for natural science learning media for elementary school
}

\author{
Ridho Hakiki ${ }^{1}$, Danang Junaedi ${ }^{2, *}$, and Emil Robert Kaburuan ${ }^{3}$ \\ ${ }^{1}$ Telkom University, School of Computing, Informatics Department, Jl. Telkomunikasi Bandung, Indonesia \\ ${ }^{2}$ Telkom University, School of Computing, Information Technology Department, Jl. Telkomunikasi Bandung, Indonesia \\ ${ }^{3}$ Bina Nusantara University, Information System Management, Jl. Kebon Jeruk Jakarta - Indonesia
}

\begin{abstract}
This research presents the user interface design for natural science learning media in the form of snakes and ladders game for 4th grader of elementary school. Natural science becomes a problem for children because the way the teacher explains and media used is not maximal. The result is presented when students got poor grade and understanding. Elementary school children characteristic is playful, playing become the most effective way for children to learn. Snakes and ladders game developed by Daluti Delimanugari is used as learning media of natural science but this media still lack flexibility and practically. Technology is interesting to children because it presents motions, dimensions, sounds, colors, songs and varying materials. Children do not get those advantages from using other media. Therefore, this paper suggested a solution which is snakes and ladders game application as learning media for natural science. User-centered design used for designing the user interface focuses on the characteristic, task and environment of the users. The results of usability testing of the ladder snake game application that has been built obtain an average of $88.8 \%$.
\end{abstract}

\section{Introduction}

Science or Natural Science is one of the subjects studied at 4th grader of elementary school [1]. Natural science subject becomes a problem for children because the way the teacher explains and media used is still not meet the needs of the students. As a result, children gained low score in natural science. According to Trends in International Mathematics and Science Study (TIMSS) at 2015 , it showed that Indonesian children from 4th grade is only able to reach score at 397 and is in the 45th position of 48 countries at natural science [2].

Elementary school children in Indonesia are aged 712 years old, the characteristic of children at that age is playful, most activities are conducted in a group [3]. According to Jean Piaget, children at the age of 7 to 11 are in a concrete operational phase, children at that phase find it hard to comprehend lesson if it is not concrete for children. For elementary school children, playing become the most effective way for children to learn [4].

In 2015, Daluti Delimanugari [5] researched a board game used as natural science learning media. The result of this research is a snakes and ladders game in board shape named Petir Pelangi; the game got a very good category, so it is used as a natural science learning media. But, the game is lacking flexibility and practicality, it needs a teacher to accompany, requires a large space because the board sized 1x1 meter and consisted of separate components. With those weaknesses, the game is impossible to play anytime and anywhere.

Elementary school children are known to have interest in technology specifically Smartphone. Based on Ministry of Communication and UNICEF survey in 2014 and survey from Indonesia Hottest Insight in 2013, $79.5 \%$ of Smartphone user specifically in Indonesia is children and teenagers, $40 \%$ children realize the existence of technology and use it to gain information, entertainment and to make social relationships. Technology becomes something interesting to children because it presents dimensional motions, sounds, colors, songs and varying materials [6]. Children use technology anytime and anywhere, one of the technologies is Smartphone-based technology. With those advantages, children can access information and entertainment at once. Mobile learning is an approach to electronic learning that simply utilises mobile devices [7].

In designing the application, we need to consider usability factors. Usability of an application is influenced by UI because UI is the interaction link between user and application. If UI does not match the user, the user will find it difficult to get the required information [8]. The method that can be used in designing model UI application is User-Centered Design (UCD) method. UCD focuses on user's characteristics, task, and environment [9]. By applying UCD method, the media built can match the user's characteristics.

\footnotetext{
* Corresponding author: danangjunaedi@telkomuniversity.ac.id
} 


\section{User-centered research methods \\ design and}

User-Centered Design (UCD) is one of the methods in designing user interface focuses on characteristic, task and environment. The process of UCD is in the figure below:

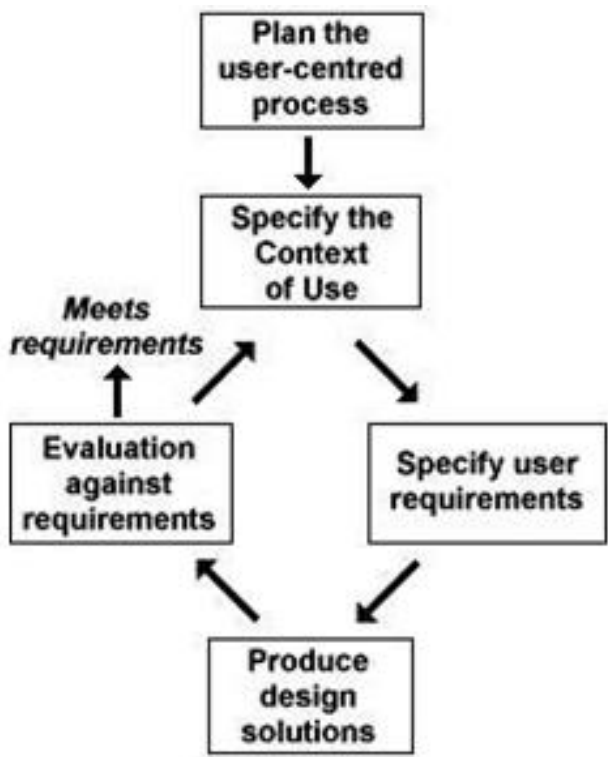

Fig. 1. UCD process [10].

\subsection{Specify the context of use}

The researcher conducted interviews and observations to 5 children of the elementary school, the interviews and observations are done with five users accordance to Jakob Nielsen research. Jakob Nielsen [11] stated that in doing user research at least requires five people. Jakob Nielsen research also showed that the test results obtained had reached more than $85 \%$. This User research is conducted to get the persona's data. Persona has several aspects such as demographics, skill, behavior, environment which will be influential in making design solution. The purpose of persona is to represent the actual user and to know what makes the user frustrated and enjoy in using something. The table below is children persona in this research:
Table 1. Children persona.

\begin{tabular}{|c|c|}
\hline Aspect & Persona \\
\hline \multirow{2}{*}{ Demographic } & 10 years old \\
\hline & Students of Elementary School \\
\hline Technology & Smartphone owner \\
\hline \multirow{4}{*}{ Skill } & Language: Bahasa Indonesia \\
\hline & Able to operate smartphone \\
\hline & Able to play snakes and ladder game \\
\hline & Able to do the task given \\
\hline \multirow{3}{*}{ Behavior } & $\begin{array}{l}\text { Play snakes and ladder game together with a } \\
\text { friend }\end{array}$ \\
\hline & $\begin{array}{l}\text { Learn natural science by doing the question } \\
\text { exercises and reading the material } \\
\text { summaries }\end{array}$ \\
\hline & Ask parents if finding any difficulties \\
\hline \multirow{3}{*}{ Environment } & Use smartphone at home \\
\hline & Play snakes and ladder game at home \\
\hline & $\begin{array}{l}\text { Learn natural science both at school and } \\
\text { home }\end{array}$ \\
\hline \multirow{3}{*}{ Motivations } & $\begin{array}{l}\text { Use Smartphone to play a game and social } \\
\text { media }\end{array}$ \\
\hline & $\begin{array}{l}\text { Play snakes and ladder game to get rid of } \\
\text { boredom and play together with friends }\end{array}$ \\
\hline & $\begin{array}{l}\text { Lear natural science to get good grades in } \\
\text { class and to get rank in class }\end{array}$ \\
\hline
\end{tabular}

\subsection{Specify user requirements}

Needs collected from the user is modified into requirements in the form of features. The features concluded after conducting interviews and observations to children are as follows:

- Children get a game with supplement natural science learning content

- Children can learn natural science through question exercises and provided material

- Children can use help option when having problem while learning

- Children can play the game together with friend

\subsection{Produce design solutions}

Based on the results of data collection, the researcher created a user interface which has features according to the users' needs. The figure below is the user interface of snakes and ladders game that allows children to play the game with friends according to the number of player, pawns, and players' turn. 


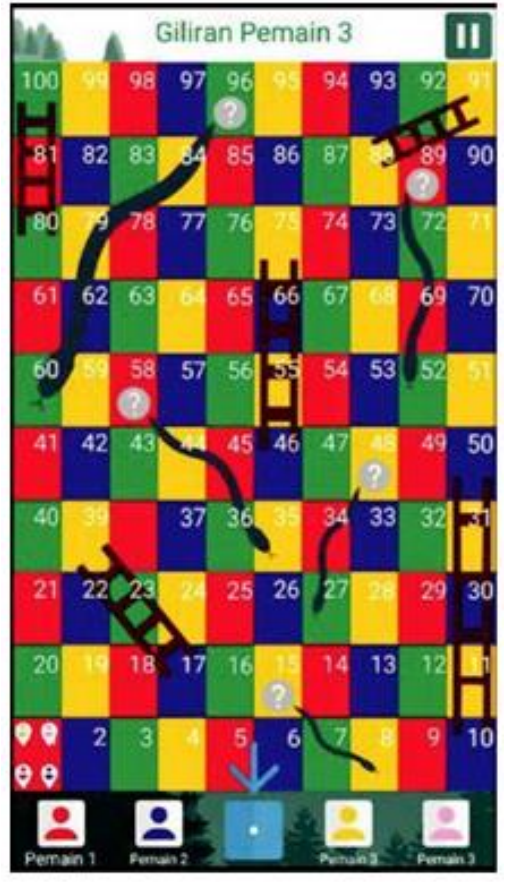

Fig. 2. User interface for snakes and ladders game.

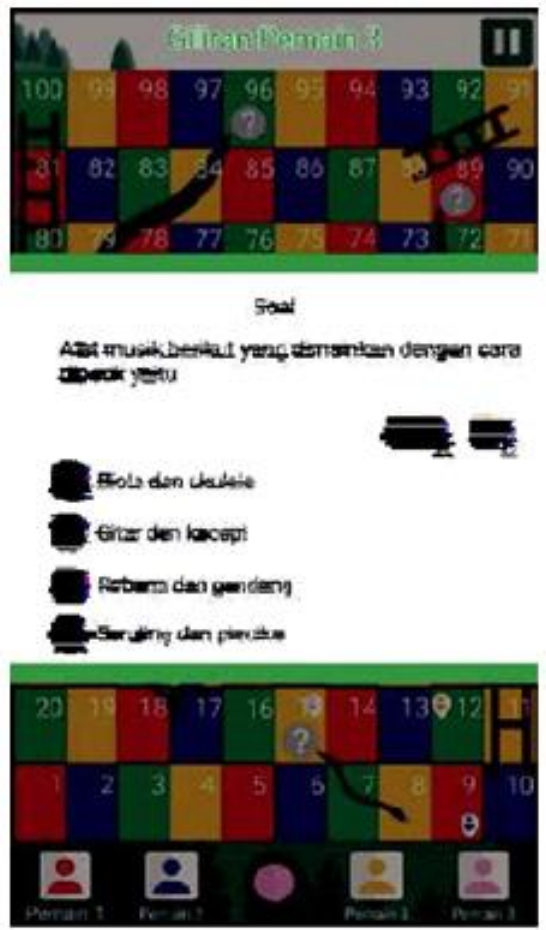

Fig. 3. User interface for learning content.

The user interface design allows children to learn natural science through the content of questions and material which followed the school's curriculum. Children can use help option when having problem with the tasks given.

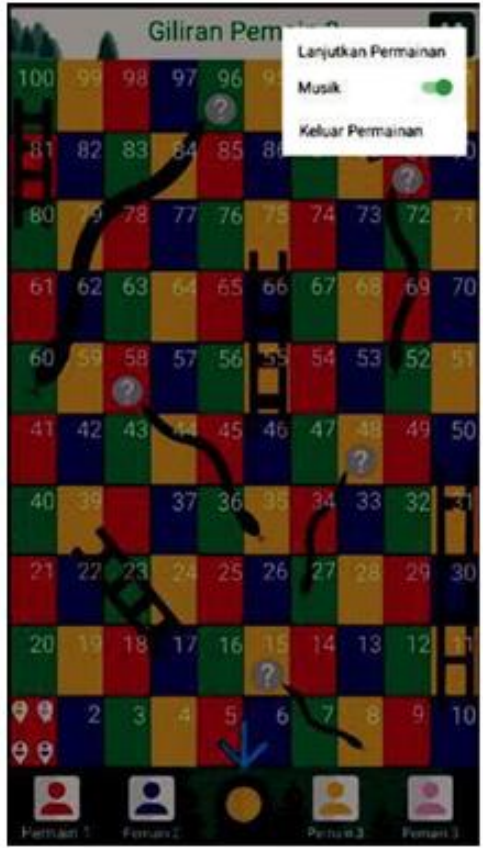

Fig. 4. User interface for pause menu.

The user interface allows children to pause or continue the game, turn on and off the music. This provides more freedom and flexibility in playing and learning.

\subsection{Evaluation against requirements}

We use Quality of Use Integrated Measurement (QUIM) method. QUIM to measure actual usage and identified a problem in software [12]. QUIM consists of 10 factors such as efficiency, effectiveness, productivity, satisfaction, learnability, safety, trustfulness, accessibility, universality, and usefulness.

We set the percentage criterion for a range value. The range value is obtained from the largest percentage value reduced by the smallest percentage value divided by the number of measurement scales. Following is the result:

Table 2. Criteria range value of evaluation.

\begin{tabular}{|c|c|}
\hline Interval & Percentage Category \\
\hline $85 \%-100 \%$ & Excellent \\
\hline $69 \%-84 \%$ & Good \\
\hline $53 \%-68 \%$ & Adequate \\
\hline $37 \%-52 \%$ & Deficient \\
\hline $20 \%-36 \%$ & Poorly \\
\hline
\end{tabular}

The QUIM percentage for users' evaluation on children as follows: 


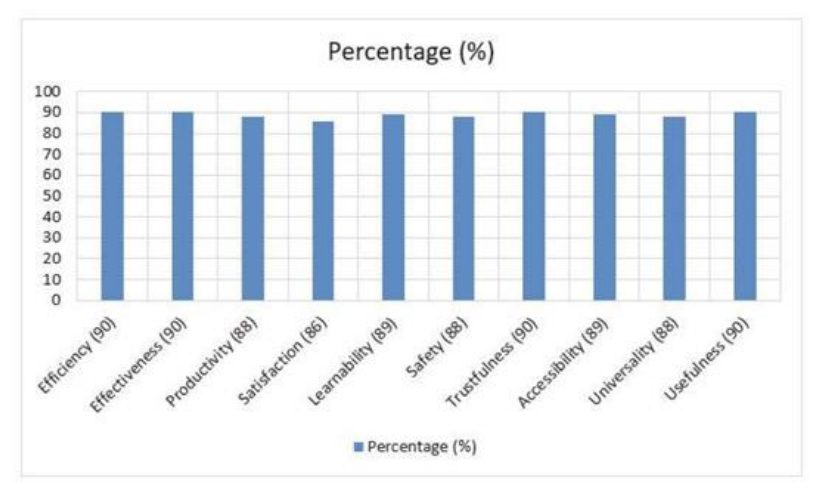

Fig. 5. Evaluation result.

Analysis based on evaluation result is as follows:

- For each factor, the percentage has more than $85 \%$ with an average rate of $88.8 \%$. This result shows that the users accept our user interface model.

- This shows that the built user interface model can be said to be very good and in accordance with the needs of the child.

- Based on the percentage for satisfaction and trustfulness factor, it can be seen that the interest of the child toward natural science learning in application has been very good. Children interested in natural science learning on the user interface model caused by learning aid and can be played together with friends. However, children expect the amount of learning content on the user interface model to be enriched.

- From result of productivity and usefulness factor, it can be seen that user interface model can be used as learning media of natural science. This is because children are able to learn natural science through learning content is a matter and a summary that has been in accordance with the curriculum of natural sciences that apply.

\section{Conclusions}

A snakes and ladders game named Petir Pelangi [5] that used as a natural science learning media is modelled into a user interface of game application. Model User Interface for snakes and ladders game application as natural science learning media for elementary school children using UCD method can be concluded:

- Model user interface from snakes and ladders game application has been able to provide a solution as natural science learning media. Some of the users getting question and using summary as help to answer the question. This snakes and ladders game features such as choosing the number of players, picking pawns, determining the players' turn, rolling dice, moving the pawn. The average of usability result of snakes and ladders game application is $88,8 \%$.

- The model user interface for snakes and ladders game application has weaknesses such as a limited number of question, the questions are only obtained from books used by children. Therefore, in further research can add teacher access to add questions so the question increases and varies along with an increase in usability factor.

\section{References}

1. Kementrian Pendidikan dan Kebudayaan, Jendela Interaksi Kurikulum [Online] Available: http://kurikulum.kemdikbud.go.id/ [Accessed 18 Oktober 2016] (2016)

2. IEA International Association for the Evaluation of Educational Achievement, TIMSS 2015 [Online]. Available: content/uploads/filebase/full\%20pdfs/T15 International-Results-in-Science-Grade-4.pdf. [Accessed 16 Januari 2017] (2016)

3. F. Astri, Memunculkan Daya Tarik Pelajaran Sains [Online]. Available: https://pgsd.binus.ac.id/2016/06/29/memunculkandaya-tarik-pelajaran-sains/. [Accessed 8 Januari 2018] (2016)

4. Sekolah Dasar Gemala Ananda, Bermain dan Perkembangan Anak 6-12 tahun [Online]. Available:

http:/www.gemalaananda.sch.id/2014/06/02/bermai n-dan-perkembangan-anak-6-12-tahun/. [Accessed 1 Januari 2018] (2014)

5. D. Delimanugari, Pengembangan Media Permainan Ilmu Pengetahuan Alam untuk Meningkatkan Minat dan Hasil Belajar Siswa MI/SD di Gunungkidul.

6. P. Y. Wulandari, Anak Asuhan Gadget, [Online]. Available:

http://health.liputan6.com/read/2460330/anakasuhan-gadget. [Accessed 17 Desember 2017] (2016)

7. A. Kukulska-Hulme, J. Traxler, Mobile teaching and learning," in Mobile Learning: A Handbook for Educators and Trainers (London: Routledge, 2005)

8. P. Pidoco, User Interface Design (UI Design) [Online]. Available: https://pidoco.com/en/help/ux/user-interface-design. [Accessed 2018 Januari 8]

9. J. Nielsen, Nielsen Norman Group [Online]. Available: https://www.nngroup.com/articles/whyyou-only-need-to-test-with-5-users/. [Accessed 10 Juli 2017].

10. S. L. Henry, Just Ask: Integrating Accessibility Throughout Design. Lulu.com (2007)

11. Usability Partners, Standards in Usability and UserCentred Design [Online]. Available: http://www.usabilitypartners.se/about-usability/isostandards.php. [Accessed 16 Januari 2017]

12. A. Seffah, M. Donyaee, R. B. Kline, H. K. Padda, Usability measurement and metrics: A consolidated model, Software Qual J. 14, 2, 166-172 (2006) 